\title{
Sustainable and Environmentally Friendly Essential Oils Extracted from Pineapple Waste
}

\author{
Wafaa M. Hikal 1,2 (i), Hussein A. H. Said-Al Ahl ${ }^{3}$ (D), Kirill G. Tkachenko ${ }^{\text {(D) }}$, Amra Bratovcic ${ }^{5}$ (D),

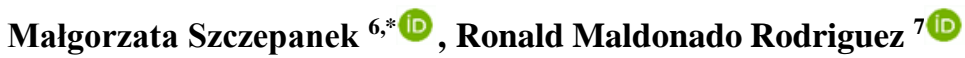

1 Department of Biology, Faculty of Science, University of Tabuk, P.O. Box 741, Tabuk 71491, Saudi Arabia; wafaahikal@gmail.com (W.M.H.);

2 Water Pollution Research Department, Environmental Research Division, National Research Centre, 33 El-Bohouth St., Dokki, Giza, 12622, Egypt; wafaahikal@gmail.com (W.M.H.);

3 Medicinal and Aromatic Plants Research Department, National Research Centre, 33 El-Bohouth St., Dokki, Giza, 12622, Egypt; shussein272@yahoo.com (H.A.H.S.A.A.);

4 V. L. Komarov Botanical Institute of the Russian Academy of Sciences, Saint Petersburg, Russia; kigatka@gmail.com (K.G.T.);

5 Department of Physical Chemistry and Electrochemistry, Faculty of Technology, University of Tuzla, Tuzla, Bosnia and Herzegovina; amra.bratovcic@gmail.com (A.B.);

6 Department of Agronomy, Bydgoszcz University of Science and Technology, S. Kaliskiego 7 Street, 85-796 Bydgoszcz, Poland; malgorzata.szczepanek@utp.edu.pl (M.S.);

7 The Fluoromatics Laboratory, 10 Rue du Vieux-Moulin, 1213 Onex, Geneva, Switzerland; info@fluoromatics.com (R.M.R.);

* Correspondence: malgorzata.szczepanek@utp.edu.pl (M.S.);

Scopus Author ID 56627700600

Received: 3.09.2021; Revised: 1.10.2021; Accepted: 4.10.2021; Published: 20.11.2021

Abstract: Pineapple (Ananas comosus (L.) Merril), one of the major fruit crops, is mainly used for raw consumption and for industrial juice production, which creates large amounts of residues. The United Nations Food and Agriculture Organization (FAO) has estimated that pineapple waste accounts for between 50 to $65 \%$ of the total weight of the fruit. Industrial pineapple waste is a major source of pollution as important quantities of primary residues are not further processed. Pineapple waste contains bioactive compounds such as carotenoids, polyphenols, fibers, vitamins, enzymes, and essential oils. These phytochemicals can be used in the food industry, medicine and pharmacy, textile, and others. This review highlights essential oil and other bioactive compounds extracted from pineapple waste and the composition of pineapple essential oil. Pineapple peels are the potential raw material for essential oil extraction through various methods. Modern spectrometric methods have shown that essential oil extracted from pineapple waste comprises esters, alcohols, aldehydes, and ketones. From this overview, it can be concluded that there is an important need for further research into pineapple waste as a potential source of valuable byproducts, as well as new techniques to studying industrial organic residuals to achieve higher recovery rates of valuable bioactive compounds used in pharmaceuticals, cosmetic and chemical industries as well as for developing new functional foods.

Keywords: Ananas comosus; bioactive compounds; byproducts; essential oils; pineapple peel.

(C) 2021 by the authors. This article is an open-access article distributed under the terms and conditions of the Creative Commons Attribution (CC BY) license (https://creativecommons.org/licenses/by/4.0/).

\section{Introduction}

Horticultural waste is a rich source of bioactive compounds [1]. In the past, horticulture byproducts have not been considered as a source of valuable materials. An overview of the research literature shows us that there has been a steadily growing research interest in fruit industry waste as a source for recovering highly valuable biomolecules [2-8]. Studies on 
horticultural byproducts have shown that they are excellent sources of pigments, phenolic bioactive compounds, dietary fiber, saccharide derivatives, enzymes, organic acids, minerals. Several of these bioactive compounds have health-promoting properties: antibacterial, antitumoral, antiviral, antimutagenic, and cardioprotective effects [9-15].

The proper use of waste from horticultural commodities may become an initiative for sustainable development to alleviate environmental problems like waste disposal and reduce it by recycling into raw materials or converting it into useful byproducts as well as improve human health through health-enhancing substances (phenols, carotenoids, and other pigments, vitamins, fiber, among several others). Galanakis reported that horticultural waste is a rich source of phytochemicals and has been studied to extract phenolic compounds, fiber, and other bioactive compounds [16]. Most horticultural crops produce fruits and vegetables where only the pulp is consumed. Studies have shown that seeds, peels, and other fruit and vegetable byproducts that contain significant amounts of phytochemicals and essential nutrients are usually not consumed [17-20].

Pineapples are used in juice and pulp extraction, jams, and frozen pulp production, creating significant amounts of waste. Pineapple waste is a byproduct of the pineapple processing industry and typically consists of leftover pulp, peel, and skin. However, many parts of the pineapple are unused, such as leaves, stems, outer skin, and others |(Figure 1), that can be reused to make new products. Pineapple waste is produced in large quantities worldwide [21-25]. In current industrial practice, pineapple core, peel, and leaves are considered waste. It has been estimated that $40-50 \%(\mathrm{w} / \mathrm{w})$ of the total processing waste is composed of peels, kernel (core), and pomace; the canning industry of pineapple juice contributes $60 \%$ of the total produced pineapple waste which means that $50 \%$ of the total pineapple processed mass is finally discarded as waste.

Pineapple waste can be reduced by recycling it into raw materials or converting it into useful byproducts of higher value than the current major industrial products such as organic acids, biofuels (hydrogen and biogas, biomethanol, biobutanol, bioethanol), biopolymer fibers, and vegetable enzymes. It has been reported that pineapple waste is used as a raw material source for producing bioactive charcoal (biochar), bakery goods, animal feed, vinegar production, biodegradable cellulose-based fabrics, and the production of dietary fiber [26].

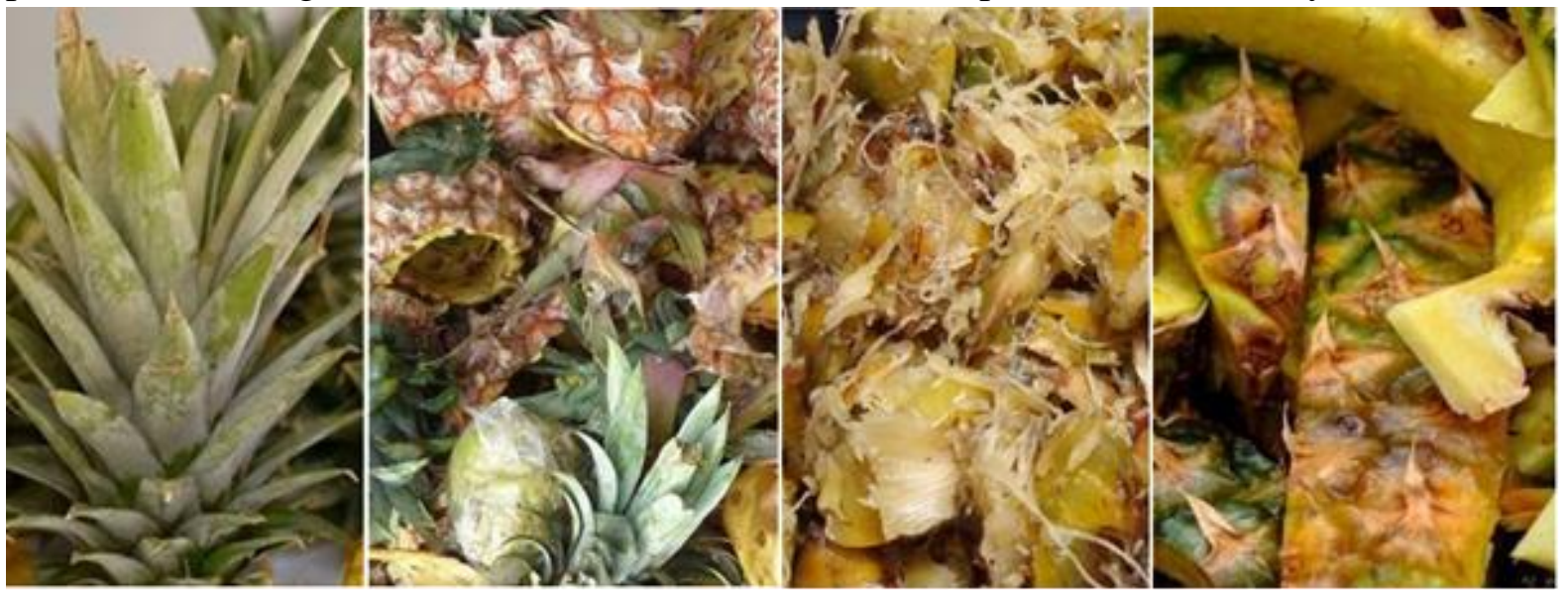

Figure 1. Pineapple wastes.

Pineapple (Ananas comosus, belonging to the family Bromeliaceae) is one of the most economically important tropical fruit crops in tropical and subtropical areas with a pleasant aroma and flavor. It is an edible tropical fruit that is rich in vitamins (A, C), enzymes, and antioxidants and contains carbohydrates, sugars, protein, fat, ash, fiber, flavonoids [27-32]. 
Pineapple pulp waste has been shown to contain high amounts of reducing sugars. Bromelain, a proteolytic enzyme, can be extracted from pineapple juice, pineapple plant stems, and other pineapple wastes. The extract of pineapple wastes mainly contains sucrose, glucose, fructose, and other nutrients [1]. Pineapples are consumed or served fresh, cooked, juiced, and canned in form [33] due to their nutritional and medicinal value [34-37]. This review examines the valorization of pineapple processing residues (pineapple waste) as a source of valuable bioactive compounds such as essential oils. Additionally, we look at current oil extraction methods and the current uses of pineapple essential oils.

\section{Essential Oil}

The use of essential oils in medicine and perfumes has been known since ancient times. Now, essential oils have become one of the high-value agricultural products, and as a result of increased demand, consumers prefer natural products.

Essential oils are obtained from plant raw materials in various ways, including hydrodistillation, steam distillation, and others. The various plant organs of flowers, fruits, seeds, leaves, stems, roots, seeds, bark, resin, or fruit peels are characterized by the transformation of cells to store oils known as secretory structures such as glandular trichomes, epidermal cells, secretory cells, secretory cavities, and secretory ducts [38,39].

Essential oils are widely used and are characterized by their multiple benefits for use in medicine, pharmaceutical, and food industries, as well as cosmetics and perfume industries [40], and have various biological effects [41-43]. The waste materials from horticultural crops are an important source of various organic products that can serve as a source of taste and aroma. There is also an increase in flavors and fragrances markets due to increased demand from consumers for natural, familiar, and safe sources. The essential oil composed of concentrated volatile aromatic compounds that easily evaporated, which give plants their wonderful scents.

\subsection{Bioactive compound from pineapple.}

Pineapple essential oils are available in the market; it offers a gentle scent of pineapple, where it was widely used in the production of body lotion, bath salts, scented candles, and other various personal care products [44]. The vanilla flavor is one of the most widely used flavors, and its main component is vanillin (4-hydroxy-3-methoxybenzaldehyde), which is produced from vanillic acid [45]. Natural vanillin is obtained from the fermented pods of vanilla orchids (Vanilla planifolia) [46]. Vanillin manufacturing has also been reported using alternative processes, including biotechnology, that involve fermentation and enzymatic reactions, such as an enzymatic manufacturing process. Pineapple peel residues contain ferulic acid, which is a precursor to vanillic acid. Therefore, the manufacturing production of vanillin from pineapple waste occurs through microbial biological transformation [47, 48], as shown in figure 2 [49].

The oil extracted from pineapple waste processing (the peel and fiber remaining after the juice extraction step) was found to contain 35 compounds identified as esters (37\%), alcohols (29\%), aldehydes (9\%), ketones (9\%), and acids (6\%) [50].

The pineapple peel and leaves contain essential oil consisting of esters (35\%), ketones (26\%), alcohols (18\%), aldehydes (9\%), acids (3\%), and other compounds (9\%) [38]. In another study by Huang et al. [51] examined the chemical constituents from the leaves of Ananas comosus and their biological activities. They identified eight compounds were tricin- 
4'-O-[10"-O-(8"-hydroxyl) feruloyl-(9'"-O-p-coumaroyl) glyceryl] ether; 2, 4-dichlorobenzoic acid; tricin; chrysoeriol; 1-O-p-coumaroylglycerol;1-O-feruloylglycerol; 1-O-feruloyl-3-O-pcoumaroyl-glycerol and 1, 3-O-diferuloylglycerol. Also, tricin-4'-O-[10"-O-(8"-hydroxyl) feruloyl-(9"'-O-p-coumaroyl) glyceryl] ether compound exhibited as well inhibitory activities against Staphylococcus aureus and Escherichia coli.

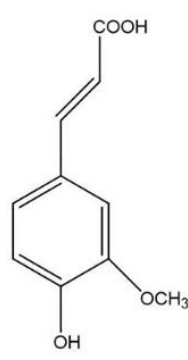

Ferulic acid

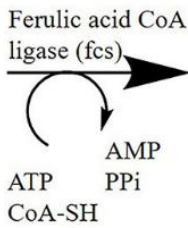

$\mathrm{CoA}-\mathrm{SH}$

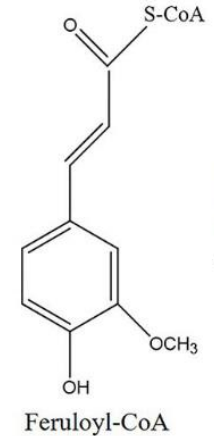

Feruloyl-CoA
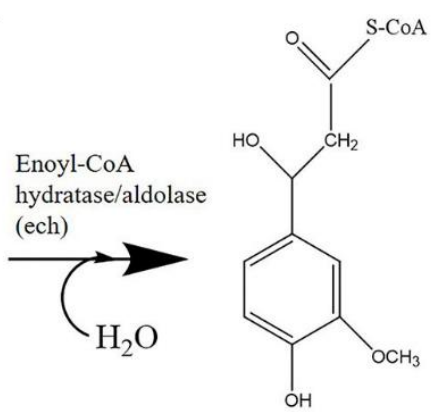

4-hydroxy-3-methoxyphenyl- $\beta$ hydroxypropionyl CoA

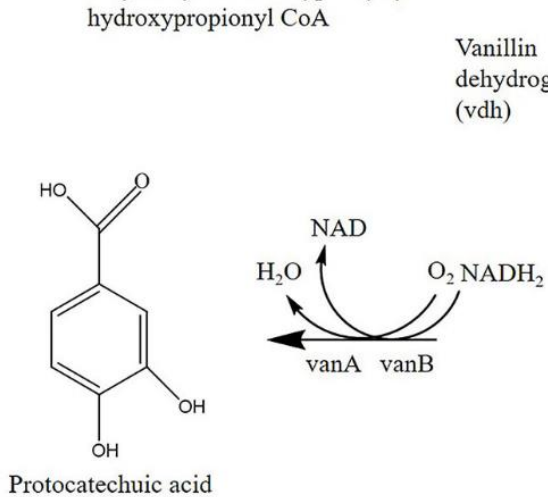

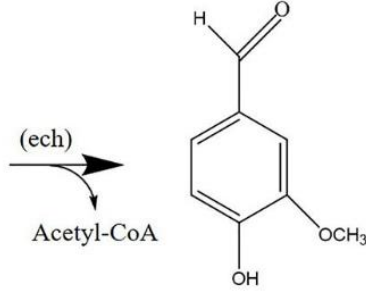

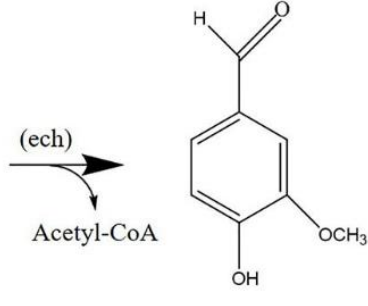

Vanillin

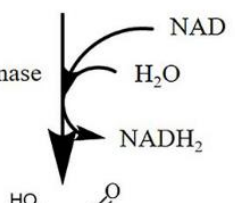

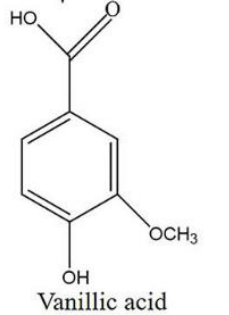

Figure 2. Bioconversion route of ferulic acid to vanillin [49].

Orodu and Ivan [52] identified seven components of oil extracted from the fruit peels of Ananas comosus, and limonene was the most abundant (76.34\%). Figure 3 shows the chemical structures of limonene. The remaining compounds identified were palmitic acid (5.38\%), n-decanal (0.95\%), 1-cyclohexene-1-carboxaldehyde (4.27\%), $\alpha$-farnesene $(1.26 \%)$, trans caryophyllene $(0.53 \%)$ and myrcene $(0.61 \%)$.<smiles>C=C(C)[C@H]1CC=C(C)CC1</smiles>

$\mathrm{R}(+)$ - limonene

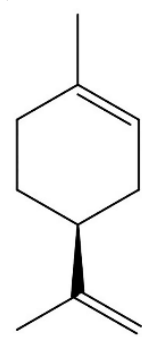

$\mathrm{S}(-)$ - limonen

Figure 3. Structures of R (+)-limonene and S (-)-limonene.

Previous studies showed that volatile aroma compounds are important and specific characteristics of each fruit type [53]. Several compounds have been identified in the pineapple peel, as shown in figure 4 [53-57]. 


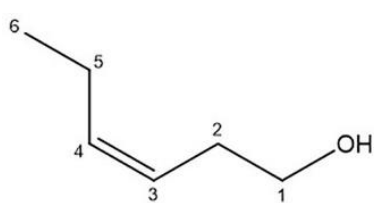

(Z)-3-hexen-1-ol<smiles>OCCc1ccccc1</smiles>

phenethyl alcohol<smiles>CCCCCCCC(=O)OC</smiles>

methyl octanoate

ethyl octanoate

Wei et al. [58] identified forty-four compounds from from the oil extracted from pineapple pulp and core. Among the compounds identified were methyl hexanoate, ethyl hexanoate, methyl 3-(methylthio) propanoate, methyl octanoate, ethyl decanoate, $\alpha$-terpineol, nonanal, and decanal. Moreover, ethyl hexanoate, nonanal, and decanal compounds are responsible for the smell in the oil extracted from pineapple pulp and core. Morais and Silva [54] confirmed that ethyl hexanoate and decanal are one of the main compounds that determine the flavor of pineapple and other compounds such as ethyl octanoate, acetic acid, 1-hexanol, and many ketones such as $\gamma$ hexalactone, $\gamma$-octalactone, $\delta$-octalactone, $\gamma$-decalactone and $\gamma$ dodecalactone. Facundo [55] pointed out that ethylhexanoate is a major compound in the oil extracted from the waste of pineapple and is responsible for the aroma of pineapple, along with ethyl octanoate, 2-heptanone, and beta-hexalactone.<smiles>COC(=O)CCSC</smiles>

methyl-3-(methylthio) propanoate<smiles>CC(=O)OC(C)C(C)OC(C)=O</smiles>

butane-2,3-dioldiacetate<smiles>CCOC(=O)C(C)CC</smiles>

ethyl-2methylbutanoate<smiles>CC1=C(O)C(=O)C(C)O1</smiles>

2,5-dimethyl-4-hydroxy 3-(2H) furanone<smiles>CCOC(C)=O</smiles>

ethyl acetate

Figure 5. Some chemical structure of some components in pineapple peel oil.

Tokitomo et al. [59] detected twenty-nine compounds in pineapple oil, the most important of which are $\gamma$-octalactone, $\delta$-octalactone, $\gamma$-decalactone, and $\gamma$-dodecalactone. Also, Elss et al. [56] found that 2-methyl-3-buten-2-ol, methyl pentanoate, butyl acetate, hexanal, 2pentanol, 1-butanol, ethyl hexanoate, limonene, z-ocimene, linalool, furfural, acetic acid, $\alpha$ terpineol, geraniol, and $\gamma$-octalactone compounds are present in pineapple oil. As well, Spanier 
et al. [57] identified acetic acid, 1-hexanol, and a non-lipidic acid in pineapple oil. Zhang et al. [60] reported that fifty-seven volatile compounds of the pineapple peel oil were detected, and the compounds were distributed as follows: twenty-five esters, nine alcohols, eight acids, seven phenolic compounds, six aldehydes and ketones, one terpene, and one lactone. Alcohol compounds predominated as they represented the highest content. Phenethyl alcohol (22.18\%), 3-methyl-1-butano (6.91\%), 2-methyl-1-butano (4.75\%), 2,3-butanediol (8.35\%), 2-methoxy4-vinylphenol (5.66\%) and octanoic acid (4.29\%). The volatile components found in $A$. comosus according to Umano et al. [61] and Teai et al. [62], were methyl-3-(methylthio) propanoate, ethyl-2methylbutanoate, ethylacetate, ethyl-3-(methylthio) propanoate, 2,5dimethyl-4-hydroxy 3-(2H) furanone and butane2,3dioldiacetate (Figure 5).

\subsection{Extraction techniques of essential oil from pineapple.}

Mohamad et al. [63], compare three different methods of extracting essential oil from pineapple peels, (1) hydro-distillation (HD); (2) Hydrodistillation with enzyme-assisted pretreatment (HDEA); and (3) supercritical fluid extraction (SFE). The results were that distillation using SFE gave the highest oil, $0.17 \%$, compared to distillation using HD and HDEA methods. The essential oil obtained from SFE method is composed of propanoic acid ethyl ester (40.25\%), lactic acid ethyl ester (19.35\%), 2-heptanol (15.02\%), propanol $(8.18 \%)$, 3-hexanone (2.60\%), and butanoic acid ethyl ester (1.58\%). Therefore, using pineapple wastes as a low-cost substrate for producing value-added products is considered one of the potential approaches in managing these wastes.

Barretto et al. [50] compare the oil components resulting from the extraction of pineapple residue using two extraction methods: simple hydro distillation and hydro distillation by passing nitrogen gas.(Z)-3-hexen-1-ol (35.58\%), methyl octanoate (26.11\%), 2-phenyl-1ethanol (13.51\%), 2-methyl-3-buten-2-ol (8.69\%), and 1-hexanol (3.84\%) are the main volatile compounds identified in pineapple residue which obtained by simple hydro-distillation. However, the major volatile compounds obtained by hydrodistillation by passing nitrogen gas were 1-hexanol (60.19\%), ethyl phenyl-acetate (14.54\%), 2-methyl-3-buten-2-ol (9.33\%), $\gamma$ butyrolactone $(2.08 \%)$, 2-phenyl ethyl-acetate $(1.72 \%)$, and ethyl octanoate $(1.19 \%)$. This suggests that using inert gas and lower temperatures helped maintain higher amounts of flavor compounds. These data indicate that pineapple processing residue contains important volatile compounds that can be extracted and used as aroma-enhancing products and have a high potential for producing value-added natural essences [50].

From the above, we find that the extraction techniques of essential oil from pineapple were represented in conventional extraction techniques such as hydro-distillation is a classical technique to extract important oils and various bioactive compounds from plant sources, and there are 3 kinds of hydro-distillation: water distillation, water, and steam distillation and steam distillation [64,65], and novel technologies.

The novel technologies have emerged due to the limitations and drawbacks of conventional methods, represented in the difficulty of obtaining oil with high purity. The use of solvents is expensive, in addition to the need for a long extraction time and the consequence of degradable compounds by heat and low extraction selectivity [66]. These limitations and the aforementioned negatives led to the development of new technologies. Recently, many emerging novels techniques are now being used for the extraction process.

Microwave-assisted extraction (MAE) is known as a novel technique for extracting various phytochemicals using microwave vitality [67-70]. Its advantages include low 
equipment size, high extraction efficiency and temperature gradient, and high-quality extraction of biologically active components from plant materials [71].

Microwave energy is a key technology in achieving the objective of sustainable and green chemistry for research, teaching, and commercial applications. Solvent-free microwave extraction has been conceived [72] that can offer high reproducibility in shorter times, simplified manipulation, reduced solvent consumption, and lower energy input. Microwave technology has proven a powerful technique to extract essential oil. Several papers have been published concerning the application of electromagnetic energy to promote heat generation inside plant material to improve the extraction rate of volatile compounds from herbal matrices [73-79]. The advantages of using microwave energy-a noncontact heat source- for the extraction of essential oils from plant materials, could include: more effective heating, faster energy transfer, reduced thermal gradients, selective heating, reduced equipment size, faster response to process heating control, faster start-up, increased production, and elimination of process steps [80]. As more attention has been devoted to microwave-assisted applications of essential oil extraction, certain variations of the method have been developed, such as compressed microwave-assisted hydro-distillation (MAHD), microwave-accelerated steam distillation (MASD) [77], vacuum microwave hydro-distillation (VMHD) [81], microwaveassisted hydro-distillation (MWHD) [82], solvent-free microwave extraction (SFME) [75], microwave steam distillation (MSD) [83] and microwave hydro-diffusion and gravity (MHG) [84]. These techniques offer a reduced analysis time, simplified manipulation and work-up, and higher purity of the final product [85-87].

\section{Biological Function}

Among the applications of essential oils is the multiple biological uses of essential oils as bactericidal, virucidal, fungicidal, antiparasitic, and insecticidal [39]. The wide range of biological activities of essential oils is due to their content of biologically active chemical compounds [39], including the biological effects of pineapple essential oils.

Huang et al. [51] studied the chemical constituents from the leaves of Ananas comosus and their biological activities. They identified eight compounds, and these were tricin-4'-O[10"-O-(8"-hydroxyl) feruloyl-(9"'-O-p-coumaroyl) glyceryl] ether; 2, 4-dichlorobenzoic acid; tricin; chrysoeriol; 1-O-p-coumaroylglycerol;1-O-feruloylglycerol; 1-O-feruloyl-3-O-pcoumaroyl-glycerol and 1, 3-O-diferuloylglycerol. Also, tricin-4'-O-[10"-O-(8"-hydroxyl) feruloyl-(9"'-O-p-coumaroyl) glyceryl] ether compound exhibited as well inhibitory activities as positive control Ciprofloxacin (CPFX) against Staphylococcus aureus and Escherichia coli.

In addition, some key compounds such as limonene which was the most abundant (over $75 \%$ of the oil), and other compounds, viz. palmitic acid, n-decanal,1-cyclohexene-1carboxaldehyde, $\alpha$-farnesene, trans caryophyllene, and myrcene, have been reported [52]. According to the relevant reports, it can be easily deduced that pineapple peels are a potential source for limonene, which is assessed as a dietary supplement and as a fragrance ingredient for cosmetic products, manufacture of food, and some medicines. Of the available compounds, 1-Cyclohexene-1-carboxaldehyde is an $\alpha, \beta$-unsaturated aldehyde used to synthesize benzopyrans and azomethine imines. $\alpha$-farnesene is used as a perfume in cosmetics. Trans caryophyllene acts as an anti-inflammatory agent, suggesting analgesic, antipyretic, and platelet-inhibitory actions. Myrcene is a powerful antibiotic, antimutagenic, analgesic, anti- 
inflammatory, and sedative effects [52]. Orodu and Inengite [34] showed that the oil extracted from pineapple peels is edible and can be used in foods industries.

Based on the pineapple peel, bioactive compounds are supposed to be promising ingredients in their potential applications as drugs, preservatives, substitutes for synthetic antioxidants, and used in the development of functional foods and industrial food applications.

\section{Conclusions}

Pineapple waste is an important environmental problem, and it is important to find ways to use this waste like important extract nutrients and bioactive compounds, and how pineapple peels become a profitable byproduct due to its unique flavor, an abundance of volatile compounds, and nutritional values, as well as the processing of waste into food and other uses. The pineapple peels could be used as a good source of non-pharmacological treatments in the form of processed foods and instant beverages and a promising source of metabolites for therapeutic, functional food, and cosmeceutical applications, besides environmentally friendly byproducts and sustainable manufacturing practices.

\section{Funding}

This research received no external funding.

\section{Acknowledgments}

This research has no acknowledgment.

\section{Conflicts of Interest}

The authors declare no conflict of interest.

\section{References}

1. Hikal, W.M.; Mahmoud, A.A.; Said-Al Ahl H.A.H.; Bratovcic, A.; Tkachenko, K.G.; Kačániová, M.; Rodriguez, R.M. Pineapple (Ananas comosus L. Merr.), waste streams, characterisation and valorisation: An Overview. Open J. Ecol. 2021, 11, 610-634, https://doi.org/10.4236/oje.2021.119039.

2. Sagar, N.A.; Pareek, S.; Sharma, S.; Yahia, E.M.; Lobo, M.G. Fruit and Vegetable Waste: Bioactive Compounds, Their Extraction, and Possible Utilization. Compr. Rev. Food Sci. Food Saf. 2018, 17, 512-531, https://doi.org/10.1111/1541-4337.12330.

3. Said-Al Ahl, H.A.H.; Astatkie, T.; Hikal, W.M. Opuntia ficus-indica (cactus pear) multipurpose plant for the future. Book, Noor Publishing; Noor Publishing, OmniScriptum GmbH \& Co. KG Bahnhofstraße 28, 66111 Saarbrücken, Germany. 2017.

4. Hikal, W.M.; Said-Al Ahl, H.A.H.; Tkachenko, K.G. Present and future potential of antiparasitic activity of Opuntia ficus-indica. Trop. J. Nat. Prod. Res. 2020, 4, 672-679, https://doi.org/10.26538/tjnpr/v4i10.3.

5. Hikal, W.M.; Said-Al Ahl, H.A.H.; Kacaniova, M. A review of antimicrobial activities of cactus (Opuntia ficus-indica). Asian J. Biol. Sci. 2021, 3, 10-17.

6. Santos, D.I.; Martins, C.F.; Amaral, R.A.; Brito, L.; Saraiva, J.A.; Vicente, A.A.; Moldão-Martins, M. Pineapple (Ananas comosus L.) byproducts valorization: Novel bio ingredients for functional foods. Molecules 2021, 26, https://doi.org/10.3390/molecules26113216

7. Campos, D.A.; Gómez-García, R.; Vilas-Boas, A.A.; Madureira, A.R.; Pintado, M.M. Management of fruit industrial by-products - a case study on circular economy approach. Molecules 2020, 25, https://doi.org/10.3390/molecules25020320.

8. Santos, D.I.; Pinto, C.A.; Corrêa-Filho, L.C.; Saraiva, J.A.; Vicente, A.A.; Moldão-Martins, M. Effect of moderate hydrostatic pressures on the enzymatic activity and bioactive composition of pineapple byproducts. J. Food Process. Eng. 2020, https://doi.org/10.1111/jfpe.13537

9. Djilas, S., Čanadanović-Brunet, J.; Ćetković, G. By-products of fruits processing as a source of phytochemicals. Chem. Ind. Chem. Engr. Quart. 2009, 15, 191-202, https://doi.org/10.2298/CICEQ0904191D. 
10. Yahia, E.M. The contribution of fruits and vegetables to human health. In: Fruit and vegetable phytochemicals: chemistry, nutritional value and stability. De la Rosa, L.; Alvarez-Parrilla, E.; GonzalezAguilar, G. Eds.; Ames, Iowa, Wiley-Blackwell Publishing, 2010; pp. 3-51.

11. Yahia, E.M. Fruit and vegetable phytochemicals: Chemistry and human health. Ames, Iowa: WileyBlackwell Publishing. 2017.

12. Hikal, W.M.; Kacaniova, M.; Said-Al Ahl, H.A.H. Banana peels as possible antioxidant and antimicrobial agents. Asian J. Agric. Res. 2021, 3, 35-45.

13. Chakraborty, A.J.; Mitra, S.; Tallei, T.E.; Tareq, A.M.; Nainu, F.; Cicia, D.; Dhama, K.; Emran, T.B.; SimalGandara, J.; Capasso, R. Bromelain a potential bioactive compound: A comprehensive overview from a pharmacological perspective. Life 2021, 11, https://doi.org/10.3390/life11040317.

14. Santos, D.I.; Fraqueza, M.J.; Pissarra, H.; Saraiva, J.A.; Vicente, A.A.; Moldão-Martins, M. Optimization of the effect of pineapple byproducts enhanced in bromelain by hydrostatic pressure on the texture and overall quality of silverside beef cut. Foods 2020, 9, https://doi.org/10.3390/foods9121752.

15. Campos, D.A.; Ribeiro, T.B.; Teixeira, J.A.; Pastrana, L.; Pintado, M.M. Integral valorization of pineapple (Ananas comosus L.) Byproducts through a green chemistry approach towards added value ingredients. Foods 2020, 9, https://doi.org/10.3390/foods9010060.

16. Galanakis, C.M. Recovery of high added-value components from food wastes: conventional, emerging technologies and commercialized applications. Trends Food Sci. Technol. 2012, 26, 68-87, https://doi.org/10.1016/j.tifs.2012.03.003.

17. Rudra, S.G.; Nishad, J.; Jakhar, N.; Kaur, C. Food industry waste: mine of nutraceuticals. Int. J. Sci. Environ. Technol. 2015, 4, 205-29.

18. Thatchajaree, M.; Muhammad, M.B.; Anil, K.A. Comparative extraction of bromelain and bioactive peptides from pineapple byproducts by ultrasonic- and microwave-assisted extractions. J. Food Process Eng. 2021, 44, https://doi.org/10.1111/jfpe.13709.

19. Zhou, W.; Ye, C.; Geng, L.; Chen, G.; Wang, X.; Chen, W.; Sa, R.; Zhang, J.; Zhang, X. Purification and characterization of bromelain from pineapple (Ananas comosus L.) peel waste. Food Sci. 2021, 86, 385-393, https://doi.org/10.1111/1750-3841.15563.

20. Gul, A.; Siddiqui, M.; Arain, H.; Khan, S.; Khan, H., Ishrat, U. Extraction, partial purification and characterization of bromelain from pineapple (Ananas comosus) crown, core and peel waste. Braz. Arch. Biol. Technol. 2021, 64, https://doi.org/10.1590/1678-4324-2021200639

21. Rodríguez, R.; Jiménez, A.; Guillén, R.; Heredia, A.; Fernández-Bolaños, J. Postharvest changes in white asparagus cell wall during refrigerated storage. J. Agric. Food Chem. 1999, 47, 3551-3557, https://doi.org/10.1021/jf981295r.

22. Rodríguez, R.; Jiménez, A.; Fernández-Bolaños, J.; Guillén, R.; Heredia, A. Dietary fibre from vegetable products as source of functional ingredients. Trends Food Sci. Technol. 2006, 17, 3-15, https://doi.org/10.1016/j.tifs.2005.10.002.

23. Benzonan, N.C.; Dalisay, L.C.S.; Reponte, K.C.C.; Mapanao, C.P.; Alvarez, L.V.; Rendon, A.O.; Zurbano, L.Y. Plant-parasitic nematodes associated with pineapple (Ananas comosus) in selected provinces in Luzon, Philippines. Eur. J. Mol. Clin. Med. 2021, 8, 2, 945-957.

24. Pineapple. Britannica Online Encyclopedia. Available at: www.britannica.com/print/article/460976. Accessed on April 15, 2021.

25. Pineapple. New World Encyclopedia online. April 2008. Available at: www.newworldencyclopedia.org/p/index.php?title=Pineapple\&oldid=682322. Accessed April 15, 2021.

26. [Primary Information Services www.primaryinfo.com].

27. Da Silva, D.I.; Nogueira, G.D.; Duzzioni, A.G.; Barraza, M.A. Changes of antioxidant constituents in pineapple (Ananas comosus) residue during drying process. Ind. Crop. Prod. 2013, 50, 557-562, https://doi.org/10.1016/j.indcrop.2013.08.001.

28. Brito, T.B.N.; Pereira, A.P.A.; Pastore, G.M.; Moreira, R.F.A.; Ferreira, M.S.L.; Fai, A.E.C. Chemical composition and physicochemical characterization for cabbage and pineapple byproducts flour valorization. LWT 2020, 124, https://doi.org/10.1016/j.lwt.2020.109028.

29. Ali, M.; Hashim, N.; Aziz, S.; Lasekan, O. Pineapple (Ananas comosus): A comprehensive review of nutritional values, volatile compounds, health benefits, and potential food products. Food Res. Int. 2020, 137, 1-13, https://doi.org/10.1016/j.foodres.2020.109675.

30. Bromelain. NIH National Center for Complementary and Integrative Health. Available at www.nccih.nih.gov/health/bromelain. Accessed on May 28, 2021.

31. Abbas, S.; Shanbhag, T.; Kothare, A. Applications of bromelain from pineapple waste towards acne. Saudi Journal of Biological Sciences 2021, 28, 1001-1009, https://doi.org/10.1016/j.sjbs.2020.11.032.

32. Perez, J. Features and news, food as medicine: Pineapple (Ananas comosus, Bromeliaceae). American Botanical Council. HerbalEGram 2021, 18.

33. Hossain, M.F. World Pineapple Production: An Overview. African J. Food, Agric. Nutr. Dev. 2016, 16, 11443-11456, https://doi.org/10.18697/ajfand.76.15620.

34. Orodu, V.E.; Inengite, A.K. Extraction and physicochemical analysis of oil extracted from pineapple (Ananas comosus) peels. World J. Pharm. Res. 2018, 7, 154-166. 
35. Martins, C.F.; Pestana Assunção, J.; Ribeiro Santos, D.M.; Madeira, M.S.M.D.S.; Alfaia, C.M.R.P.M.; Lopes, P.A.A.B.; Coelho, D.F.M.; Cardoso Lemos, J.; de Almeida, A.; Mestre Prates, J.A.; Freire, J.P.B. Effect of dietary inclusion of Spirulina on production performance, nutrient digestibility and meat quality traits in post-weaning piglets. J. Anim. Physiol. Anim. Nutr. 2020, 105, 247-259, https://doi.org/10.1111/jpn.13470.

36. Pineapple. USDA Food Data Central. Available at: https://fdc.nal.usda.gov/fdc-app.html\#/fooddetails/169124/nutrients. Accessed on May 28, 2021.

37. Cunha, J.M.; Freitas, M.S.M; de Carvalho, A.J.C.; Caetano, L.C.S.; Vieira, M.E;, Peçanha, D.A.; Lima, T.C.; de Jesus, A.C.; Pinto, L.P. Pineapple yield and fruit quality in response to potassium fertilization. J. Plant Nutr. 2021, 44, 865-874, https://doi.org/10.1080/01904167.2021.1871755.

38. Djilani, A.; Dicko, A. The therapeutic benefits of essential oils. In: Nutrition, well-being and health. Bouayed, J. IntechOpen, 2012; pp. 155-167.

39. Said-Al Ahl, H.A.H.; Hikal, W.M.; Mahmoud, A.A. Essential oils: Biosynthesis, chemistry and biological functions. J. Chem. Pharm. Res. 2017, 9, 190-200.

40. Evans, C. Trease and Evans Pharmacognosy. 13 ${ }^{\text {th }}$ Edition, Saunders, W.B. Eds., 2013; pp. 253-288.

41. Schelz, Z.; Molnar, J.; Hohmann, J. Antimicrobial and plasmid activities of essential oils. Fitoterapia 2006, 77, 279-285, https://doi.org/10.1016/j.fitote.2006.03.013.

42. Hammer, K.A.; Carson, C.F.; Riley, T.V. Antimicrobial activity of essential oils and other plant extracts. $J$. Appl. Microb. 1999, 86, 985-990, https://doi.org/10.1046/j.1365-2672.1999.00780.x.

43. Fleischer, T.C.; Mensah M.L.K; Mensah, A.Y.; Komlaga, G.; Gbedema, S.Y.; Skaltsa, H. Antimicrobial activity of essential oils of Xylopia aethiopica. Afr. J. Tradit. Complement. Altern. Med. 2008, 5, 391-393, https://doi.org/10.4314/ajtcam.v5i4.31295.

44. Fuller, J. Pineapple essential oil benefits. Available at: https://foryourmassageneeds.com Accessed on July 18,2020

45. Tilay, A.; Bule, M.; Kishenkumar, J.; Annapure, U. Preparation of ferulic acid from agricultural wastes: its improved extraction and purification. J. Agric. Food. Chem. 2008. 56, 7644-8, https://doi.org/10.1021/jf801536t.

46. Panouill'e, M.; Ralet, M.C.; Bonnin, E.; Thibault, J.F. Recovery and reuse of trimmings and pulps from fruit and vegetable processing. In: Handbook of waste management and co-product recovery in food processing. Waldron, K.W. Cambridge, Woodhead Publishing Limited. 2007; pp. 417-47, https://doi.org/10.1533/9781845692520.4.417.

47. Priefert, H.; Rabenhorst, J.; Steinbuchel, A. Biotechnology production of vanillin. Appl. Microbiol. Biotechnol. 2001, 56, 296-314, https://doi.org/10.1007/s002530100687.

48. Lun, O.K.; Wai, T.B.; Ling, L.S. Pineapple cannery waste as a potential substrate for microbial biotransformation to produce vanillic acid and vanillin. Int. Food. Res. J. 2014, 21, 953-958.

49. Gallage, N.J.; Mølle, B.l. Vanillin-bioconversion and bioengineering of the most popular plant flavor and its de novo biosynthesis in the vanilla orchid. Mol. Plant 2015, 8, 40-57, https://doi.org/10.1016/j.molp.2014.11.008.

50. Barretto, L.C.; Moreira, J.D,; Santos, J.A.; Narendra, N.; Santos, R.A. Characterization and extraction of volatile compounds from pineapple (Ananas comosus L. Merril) processing residues. Food Sci. Technol. Inter. 2013, 33, 638-645, https://doi.org/10.1590/S0101-20612013000400007.

51. Huang, X.J.; Chen, W.H.; Ji, M.H.; Guo, F.Y. Chemical constituents from leaves of Ananas comosus and their biological activities. Chin. Tradit. Herb. Drugs 2015, 46, 949-954, https://doi.org/10.7501/j.issn.02532670.2015.07.002.

52. Orodu, V.E.; Ivan, A. Extraction and GC-MS analysis of oil extracted from pineapple (Ananas comosus) peels. Modern Phys. Chem. Res. 2021, 1, 1-8.

53. Mamo, J.; Assefa, F. Antibacterial and anticancer property of bromelain: A plant protease enzyme from Pineapples (Ananas comosus). Curr. Trends Biomedical Eng. \& Biosci. 2019, 19.

54. Morais, M.M.; Silva, M.A. Retenção de aroma na secagem em atmosfer as normal e modificada. desenvolvimento do sistema de estudo. Ciênc. Tecnol. Aliment., Campinas 2011, 31, 2, 295-302.

55. Facundo, H.V. Mudanças no perfil sensorial e de voláteis do suco de abacaxi concentrado durante o processamento. Dissertação (Mestrado em Tecnologia de Alimentos)-Faculdade de Engenharia de Alimentos, Universidade Federal do Ceará, Fortaleza, 2009; pp. 1-82.

56. Elss, S.; Preston, C.; Hertzig, C.; Heckel, F.; Richling, E.; Schreier, P. Aroma profiles of pineapple fruit (Ananas comosus [L.] Merr.) and pineapple products. LWT-Food Sci. Technol. 2005, 38, 263-274, https://doi.org/10.1016/j.lwt.2004.07.014.

57. Spanier, A.M.; Flores, M.; James, C.; Lasater, J.; Lloyd, S.; Miller, J.A. Fresh-cut pineapple (Ananas sp.) flavor. Effect of storage. In: Developments in food science. Food flavors: Formation, analysis, and packaging influences. Contis, E.T.; Ho, C.T.; Mussinan, C.J.; Parliament, T.H.; Shahidi, F.; Spanier, A.M. Eds. Elsevier, Amsterdam 1998; pp. 331-343.

58. Wei, C.; Liu, S.; Liu, Y.; Lv L.; Yang, W.; Sun, G. Characteristic aroma compounds from different pineapple parts. Molecules 2011, 16, 5104-5112, https://doi.org/10.3390/molecules16065104. 
59. Tokitomo, Y.; Steinhaus, M.; Büttner, A.; Schieberle, P. Odor-active constituents in fresh pineapple (Ananas comosus [L.] Merr.) by quantitative and sensory evaluation. Biosci. Biotechnol. Biochem. 2005, 69, 13231330, https://doi.org/10.1271/bbb.69.1323.

60. Zhang, L.; Zhou, C.; Yuan, Y.; Gong, X.; Hu, Y.; Li, J. Characterisation of volatile oil compounds of pineapple peel wine. E3S Web of Conferences 185, 04065, International Conference on Environment, Energy and Biotechnology (ICEEB 2020) Jeju Island, Korea (south), Conference $22^{\text {nd }}$ to $24^{\text {th }}$ July 2020; https://doi.org/10.1051/e3sconf/202018504065.

61. Umano, K.; Hagi, Y.; Nakahara, K.; Shoji, A.; Shibamoto, T. Volatile constituents of green and ripened pineapple (Ananas comosus [L.] Merr.). J. Agric. Food Chem. 1992, 40, 599-603, https://doi.org/10.1021/jf00016a014.

62. Teai, T.; ClaudeLafontaine, A.; Schippa, C.; Cozzolino, F. Volatile compounds in fresh pulp of Pineapple (Ananas comosus [L.] Merr.) from French Polynesia. J. Essent. Oil Res. 2001, 13, 314-318, https://doi.org/10.1080/10412905.2001.9712222.

63. Mohamad, N.; Ramli, N.; Abd-Aziz, S.; Ibrahim, M.F. Comparison of hydro-distillation, hydro-distillation with enzyme-assisted and supercritical fluid for the extraction of essential oil from pineapple peels. 3 Biotech. 2019, 9, https://doi.org/10.1007/s13205-019-1767-8.

64. Vankar, P.S. Essential oils and fragrances from natural sources. Resonance 2004, 9, 30-41, https://doi.org/10.1007/BF02834854.

65. Silva, L.V.; Nelson, D.L.; Drummond, M.F.B.; Dufossé, L.; Gloria, M.B.A. Comparison of hydro-distillation methods for the deodorization of turmeric. Food Res. Intl. 2005, 38, 1087-96, https://doi.org/10.1016/j.foodres.2005.02.025.

66. De Castro, M.L.; Garcia-Ayuso, L.E.. Soxhlet extraction of solid materials: an outdated technique with a promising innovative future. Anal. Chim. Acta 1998, 369, 1-10, https://doi.org/10.1016/S00032670(98)00233-5.

67. Paré, J.J.; Bélanger, J.M.; Stafford, S.S. Microwave-assisted process (MAPTM): a new tool for the analytical laboratory. Trends Anal. Chem. 1994, 13, 176-84, https://doi.org/10.1016/0165-9936(94)87033-0.

68. Letellier, M.; Budzinski, H. Microwave assisted extraction of organic compounds. Analysis 1999, 27, 25970, https://doi.org/10.1051/analusis: 1999116

69. Jain, T, Jain, V, Pandey, R, Vyas, A, Shukla, SS.. Microwave assisted extraction for phytoconstituents-an overview. Asian J. Res. Chem. 2009, 2, 19-25.

70. Alupului, A.; Călinescu, I.; Lavric, V. Microwave extraction of active principles from medicinal plants. $U P B$ Sci. Bull. Series B 2012, 74, 129-42.

71. Cravotto, G.; Boffa, L.; Mantegna, S.; Perego, P.; Avogadro, M.; Cintas, P. Improved extraction of vegetable oils under high-intensity ultrasound and/or microwaves. Ultrason. Sonochem. 2008, 15, 898-902, https://doi.org/10.1016/j.ultsonch.2007.10.009.

72. Wiesbrock, F.; Schubert, U.S. Microwaves in chemistry: The success story goes on. Chemistry Today (Chimica Oggi) 2006, 24, 30-34, https://doi.org/10.1002/chin.200710273.

73. Chemat, F.; Esveld, E. Microwave super-heated boiling of organic liquids: Origin, effect and application. Chem. Eng. Technol. 2001, 24, 735-744, https://doi.org/10.1002/1521-4125(200107)24:7<735::AIDCEAT735>3.0.CO;2-H

74. Chemat, F.; Smadja, J.; Lucchesi, M.E. Solvent-free microwave extraction of volatile natural compounds. European Pat. Appl. 2003, EP 1439218A1.

75. Lucchesi, M.E.; Chemat, F.; Smadja, J. Solvent-free microwave extraction of essential oil from aromatic herbs: comparison with conventional hydro-distillation. Journal of Chromatogr. A 2004, 1043, 323-327, https://doi.org/10.1016/j.chroma.2004.05.083.

76. Chemat, S.; Aït-Amar, H.; Lagha, A.; Esveld, D.C. Microwave-assisted extraction kinetics of terpenes from caraway seeds. Chem. Eng. Process. 2005, 44, 1320-1326, https://doi.org/10.1016/j.cep.2005.03.011.

77. Chemat, F.; Lucchesi, M.E.; Smadja, J.; Favretto, L.; Colnaghi, G.; Visinoni, F. Microwave accelerated steam distillation of essential oil from lavender: A rapid, clean and environmentally friendly approach. Anal. Chim. Acta 2006, 555, 157-160, https://doi.org/10.1016/j.aca.2005.08.071.

78. Lucchesi, M.E.; Smadja, J.; Bradshaw, S.; Louw, W.; Chemat F. Solvent free microwave extraction of Elletaria cardamomum L.: A multivariate study of a new technique for the extraction of essential oil. J. Food Eng. 2007, 79, 1079-1086, https://doi.org/10.1016/j.jfoodeng.2006.03.029.

79. Chemat, F.; Lucchesi, M-E. Microwave-assisted extraction of essential oils. In: Microwaves in Organic Synthesis. Wiley-VCH Verlag GmbH 2008; pp. 959-985, https://doi.org/10.1080/08327823.2013.11689846.

80. Metaxas, A.C.; Meredith, R.J. Industrial microwave heating. P. Peregrinus LTD London, UK $1983,357$.

81. Mengal, P.; Mompon, B. Method and apparatus for solvent free microwave extraction of natural products. European Pat. Appl. 1996, EP 698076B1.

82. Stashenko, E.E.; Jaramillo, B.E.; Martínez, J.R. Comparison of different extraction methods for the analysis of volatile secondary metabolites of Lippia alba (Mill.) N.E. Brown, grown in Colombia, and evaluation of its in vitro antioxidant activity. J. Chromatogr. A 2004, 1025, 93-103, https://doi.org/10.1016/j.chroma.2003.10.058. 
83. Sahraoui, N.; Vian, M.A.; Bornard, I.; Boutekedjiret, C.; Chemat, F. Improved microwave steam distillation apparatus for isolation of essential oils: Comparison with conventional steam distillation. J. Chromatogr. A 2008, 1210, 229-233, https://doi.org/10.1016/j.chroma.2008.09.078.

84. Vian, M.A.; Fernandez, X.; Visinoni, F.; Chemat, F. Microwave hydrodiffusion and gravity, a new technique for extraction of essential oils. J. Chromatogr. A 2008, 1190, 14-17, https://doi.org/10.1016/j.chroma.2008.02.086.

85. Kingston, H.M.; Jassie, L.B. Monitoring and predicting parameters in microwave dissolution. In: Introduction to Microwave Sample Preparation: Theory and Practice. 1988, pp. 93-154.

86. Kingston, H.M.; Walter, P.J.; Chalk, S.J.; Lorentzen, E.; Link, D. Environmental microwave sample preparation fundamentals, methods, and applications. In: Microwave-Enhanced Chemistry: Fundamentals, Sample Preparation, and Applications. Eds. Kingston, H.; Jassie, L. 1997; pp. 223-349.

87. Zlotorzynski, A. The application of microwave radiation to analytical and environmental chemistry. Crit. Rev. Anal. Chem. 1995, 25, 43-76, https://doi.org/10.1080/10408349508050557. 